\title{
THE EFFECT OF LEAN AND AGILE PRACTICES ON SUPPLY CHAIN OPERATIONAL PERFORMANCE IN MALAYSIA MANUFACTURING INDUSTRY
}

\author{
Khai Loon Lee ${ }^{1, *}$ Xing Qi Teh ${ }^{1}$ \\ ${ }^{1}$ Faculty of Industrial Management, Universiti Malaysia Pahang, Lebuhraya Tun Razak, 26300 Gambang, Pahang, Malaysia.
}

ABSTRACT - This study investigates the influence of lean and agile practices on supply chain operational performance in Malaysia manufacturing industry. The lack of IT flexibility, little information sharing, poor delivery performance, and low product quality affect responsiveness, reliability, agility, and cost of supply chain operational performance in Malaysia manufacturing industry. This study has utilized the Resource-Based View (RBV) theory to strengthen the framework of this study. The research objectives in this study are to investigate the effect of lean practices and analyze the effect of agile practices on supply chain operational performance in Malaysia manufacturing industry. To achieve the research objectives, a quantitative research approach is necessitated. The population of this study is 3626 manufacturing companies in Malaysia. The minimum sample size is 107 , suggested by a G-power statistical analysis software. Besides, the cluster random sampling technique is used in the sample selection. Furthermore, a total of 550 online questionnaires was distributed by email to the manufacturing industry in Malaysia and received a return of 112 responses representing a $20.36 \%$ response rate. Besides, Smart-PLS 3.0 was chosen as the software used for data analysis. Based on research findings, all of the eight hypotheses were supported. The theoretical and practical implication was presented before, the limitations and recommendations were discussed. In conclusion, lean and agile practices play a significant role in improving supply chain operational performance in the Malaysia manufacturing industry.

\author{
ARTICLE HISTORY \\ Received: 7-7-2021 \\ Revised: 16-8-2021 \\ Accepted: $12-10-2021$ \\ KEYWORDS \\ Lean practices; \\ Agile practices; \\ Supply chain operational \\ Performance; \\ Malaysia manufacturing \\ industry
}

\section{INTRODUCTION}

Supply Chain Operational Performance can be defined as activities and processes involving transforming raw materials or intermediate components to finished goods (Lee, Udin, Hassan, Bakar, \& Hanaysha, 2017). Essentially, the primary aim of a supply chain is to distribute goods and services effectively to customers in a limited time, with minimum total costs and efficiency (Naway \& Rahmat, 2019). The performance analysis shows how well a manufacturer meets its targets. It can include market attention and customer satisfaction. It has evaluated past performance in several methods, including operational performance (Shahbaz, Rasi, Ahmad, \& Sohu, 2018). It can eventually be established that an efficient supply chain is important after understanding the economic situation and the recent development of the manufacturing industry in Malaysia (Basu, Jeyasingam, Habib, Letchmana, \& Ravindran, 2017). Consequently, this study seeks to identify lean and agile practices on supply chain operational performance in the Malaysian manufacturing industry.

Gunasekaran et al. (2018) defined agile practices as four enabling competencies: information technology, Just in Time (JIT), flexibility, and responsiveness in the Malaysian manufacturing industry. The Malaysian manufacturing industry currently has the problem of sharing information, collaboration, and collaboration with supply chain partners that can influence the operational performance of the supply chain (Alzoubia \& Yanamandra, 2020). Sharing information is needed for partners to make effective and efficient use of it. The level of information sharing is intimately linked to transparency and effectiveness. Furthermore, according to Paul, Chandra, Chalup, and Raravi (2017), other challenges are poor delivery performance, which would cause significant problems in managing production activities. The lack of Just in Time in lean and agile practice to deliver performance influences customer speed and flexibility in delivering value at a sustainable, fast delivery rate, which will affect supply chain operational performance (Buergin et al., 2018). Moreover, the lack of responsiveness to new products continues to be a concern (Fowler, Kim, \& Shunk, 2019). Delaying the introduction of new products on the market would instead lead to negative consequences such as lower market dominance, lower profits, and a loss of consumer confidence (Fowler et al., 2019).

In addition, lean practice is defined as the company's skills to use its supplier relationship, Just in Time, Pull Flow, Total Quality Management (TQM), and Customer Relationship of the Malaysia manufacturing industry. Researchers also find that the research problem includes low product quality. TQM in lean practice can maintain and exceed the needs of customers in high-quality products based on constant improvement and error handling at all levels and in all aspects of the company (Sharma \& Modgil, 2019). The problem was also caused by the lack of JIT and pull flow in lean practices. 
The pull systems, such as consumer orders, will check product stocks by the final assembler and then, order the Kanban container once the stock is nearly depleted ( $\mathrm{Wu}, 2019)$.

Moreover, the lack of relationship management between provider and customer in lean practices also addresses the challenges of the Malaysian manufacturing industry. The lack of contact between suppliers and customers in the lean system will result in expensive sales, consumer loss, and the engagement between manufacturers and their customers is thought to cause a decrease in industrial output in manufacturing (Gaumer \& Shaffer, 2018). The lack of a pull flow system was also the reason for these challenges. This principle is used when continuous flow in a product flow is impossible. It is used by considering product demand and enabling the product value chain backward. The final assembly unit checks the inventory levels of items and demands by filling in the Kanban container with pull systems once the inventory tends to be devoted.

As for this study, it has limited comparisons between lean and agile operational management practices for supply chains. It can be argued that the use of versatility alone is limited when separating lean and agile practices because of development model reveals different strengths (Cheung, Chiang, Sambamurthy, \& Setia, 2018). In addition, there is also limited research on agile practices in the supply chain process (Möldner, Garza-Reyes, \& Kumar, 2020). Finally, the minimal effects of agile and lean experience on the operational efficiency of the supply chain are also available (Iyer, Srivastava, \& Srinivasan, 2019). Most of the journals showed only lean and agile production.

Based on the discussion mentioned above, a major concern of this study is "what is the relationship between lean and agile practices on supply chain operational performance"? To provide a better understanding of the concern raised, this study investigates the effect of lean practices on supply chain operational performance in the Malaysian manufacturing industry and analyzes the effect of agile practices on supply chain operational performance in the Malaysian manufacturing industry.

This study added value for future studies by suggesting and testing the effect of lean and agile practices, thus providing insights into how this can boost operational performance in the supply chain. Besides, this study can be the guideline for the supply chain managers to consider the operational success of the supply chain with the higher potential for improved productivity in manufacturing.

\section{LITERATURE REVIEW}

\section{Lean Practices}

Manufacturers have invested in implementing lean practices in various industry sectors and worldwide (Cheung et al., 2018). According to Ansah and Sorooshian (2017), it includes numerous proof that lean practices were being identified in different ways to achieve supply chain operational performance objectives. Lean practices have been developed to integrate lean philosophy/thinking into the supply chain's planning, design, and operational performance. (Babalola, Ibem, \& Ezema, 2019). Besides, lean practices include various tools to increase supply chain operational performance (Babalola et al., 2019). In operation, implementing lean practices aims to enhance productivity, improve quality, and reduce downtime and cost (Onofrei, Prester, Fynes, Humphreys, \& Wiengarten, 2019). In this study, lean practices have five dimensions: supplier relationship, Just-in-Time, pull flow, total quality management, and customer relationship.

\section{Supplier Relationship}

Supplier relationships are complex, and companies must continually increase their supplier-based performance to step beyond their current suppliers and reorganize their supply base (Amoako-Gyampah, Boakye, Adaku, \& Famiyeh, 2019; Conny Wang, Tan, \& Abdul Wahid, 2020). Collaborative activities between businesses and suppliers are becoming highly relevant in the supply chain, except for short product lifecycles, extreme global competition, and ever-increasing consumer demands (Amoako-Gyampah et al., 2019). Relationship commitment is a crucial element of the success of long-term relationships in the marketing literature (Mungra \& Yadav, 2019). Long-term relationships can achieve higher profitability (Joshi, Kharat, Raut, Kamble, \& Kamble, 2017). Increasing profits open up the supplier to the buyer to make one another more familiar and appreciated as part of improving relationships (Joshi et al., 2017). A long-term trust relationship contributes to the development of interest and income.

\section{Just in Time (Downstream)}

The main principle for JIT is to push through rather than pull through. This is to ensure that the manufacturing process begins only after the customer has put in the order. The goods are delivered on delivery, which results in a much more frequent distribution of stock (Pinto, Matias, Pimentel, Azevedo, \& Govindan, 2018). According to Babalola et al. (2019), Downstream JIT is a production system used to satisfy customer requirements demanded by the customer at the right time. The Just in Time (JIT) production system aims to prevent excess production quantity, excess inventory, and waste in waiting time. The company implements JIT systems with a low margin, which are critical for its customers, reducing its inventory and delivering on time (Chung, Talluri, \& Kovács, 2018).

\section{Pull Flow}

A pull flow system is a lean technology used in the manufacturing process to minimize waste (Beah, 2015). Essentially, the pull mechanism utilizes backward, starting with the customer's order and using visual signals to trigger action at each previous stage of the cycle (Fowler et al., 2019). The product is pulled from the customer's demand through the production line. The pull mechanism allows factories to save time to plan for future demand and produce goods that 
will never be sold (Beah, 2015). Each of these advantages of using a pull system reduces the overall cost to the company, directly or indirectly, resulting in higher profit (Beah, 2015). The pull method enables rapid material flow by applying several basic techniques, such as Kanban techniques (Mouaky, Berrado, \& Benabbou, 2019). The Kanban method is often used as a knowledge system and a lean tool to reduce waste that has no significance during a successful cycle (Mouaky et al., 2019).

\section{Total Quality Management}

Total Quality Management (TQM) is a continuous process or operation to locate, mitigate, and eliminate manufacturing errors to maximize their performance and profitability (Romero, Gaiardelli, Powell, Wuest, \& Thürer, 2019). In this context, quality measures called "quality and standard of value" typically begin with enhanced quality systems within manufacturing industries, as quality accrues on an operational level as a whole (Al-Doori, Alhorani, Social, \& 2019, 2019). It can be accomplished by enhancing staff skills through training and training courses, statistical process management, supplier controls, and quality engineering controls (e.g. tolerances and parameters) to minimize manufacturing costs and waste and improve consumer loyalty (Romero et al., 2019).

\section{Customer Relationship}

According to Ritter and Walter (2008), customer value is "the cornerstone of corporate market management due to the dominant functionality or performance in commercial markets". Every manufacturing requires the creation and maintenance of long-term customer relationships (Basu et al., 2017). An organization needs to maintain a close relationship with its customers, i.e. employer and society, to fulfil customer needs and wants at the right time (Basu et al., 2017). The main objectives of the operating supply chain are customer loyalty and customer satisfaction (Basu et al., 2017). In manufacturing activities, a company can effectively coordinate machinery, equipment, and human resources to reduce process variances, downtime, and lead times by understanding customer requests (Santouridis \& Veraki, 2017). Lastly, better shipping schemes could be built during the delivery phase to reduce the rates of late delivery (Hänninen \& Karjaluoto, 2017).

\section{Agile Practices}

Agile practices emphasize success on an extensive range of targets instead of quality and cost on their own to preserve operational performance in the supply chain. More notably, it emphasizes being first produced at the expense of mass production with leading-edge personalized goods (Gunasekaran et al., 2018). These products should meet consumer standards and disrupt rivals' strategies to the degree that the products are agents for change (Gunasekaran et al., 2018). Furthermore, agile practices provide detailed or constructive responses to customers in various ways and eventually contribute to successful product creation (Recker, Holten, Hummel, \& Rosenkranz, 2017). Agile practices can be described as an organizational strategy characterized by a strong emphasis on processes and infrastructures that are continuously adaptable and an improved approach to global knowledge to increase awareness of rapidly changing consumer needs (Gunasekaran et al., 2018). The agile practices have included information technology, Just-in-Time (JIT), flexibility, and responsiveness.

\section{Information Technology}

Information Technology (IT) allows companies to access large quantities of previously inaccessible internal and external information, making internal information management (IIM) and external information management (EIM) more critical than ever before (Prajogo, Toy, Bhattacharya, Oke, \& Cheng, 2018). IT has become increasingly important in the manufacturing industry because of its important advantages for all the industries involved (Melián-Alzola, FernándezMonroy, \& Hidalgo-Peñate, 2020). Through this context, IT increases customer loyalty, the global share of the market, efficiency, and standardization of personnel and processes, and lowers operational costs (Melián-Alzola et al., 2020). Information technology gives companies new opportunities and improves their competitive advantage (Barto, Levit, \& Hana, 2017).

\section{Just in Time (Upstream)}

In the field of upstream JIT (i.e. to suppliers), suppliers must fulfil the incoming inspection specifications as regularly as possible at the point of usage, in limited quantities, with guaranteed overall performance. To achieve advantages from Lean practices, a business needs their suppliers to balance JIT delivery and JIT production to minimize lot size and invalidate their suppliers. Suppliers support the timely delivery of JIT whilst customers make timely and correct requests (Schonberger \& Brown, 2017). Moreover, JIT pursues a zero inventory or minimises the inventory (Shang \& Ren, 2017). JIT is that the right amount of parts or goods should be manufactured at the right time. (Shang \& Ren, 2017). With the further development of the JIT concept, JIT procurement, JIT production, and JIT distribution are derived from JIT manufacturing. Shang and Ren (2017) examined the practice of JIT from the perspective of supplier JIT delivery, shortening equipment conversion time, and pull system. They used regression analysis to explore the relations among JIT time, enterprise cost, delivery time, and quality. 


\section{Flexibility}

Nowadays, flexibility is one of the marketable imperatives the manufacturing industry must enter into a pact. Flexibility typically gives companies more opportunities to diversify to meet a wide variety of business and consumer requirements. If the producer or operator can adjust the quantity, they produce quickly in response to changes in consumer demand (Amoako-Gyampah et al., 2019). Besides, the manufacturing industry, which can easily adjust its flexibility to produce different volumes and goods, without much additional cost or delay, in response to changing consumer demand or competitive behaviour, can gain more customers, increase revenue and increase profitability (Amoako-Gyampah et al., 2019). Therefore, flexibility capacity can also improve a company's competitive position and increase short-term profitability (Amoako-Gyampah et al., 2019).

\section{Responsiveness}

The responsiveness of agile practice is distinct from the responsiveness of the supply chain. Supply chain responsiveness is a constant flow of information, and the flow of products in the supply chain must be at the right time. On the other hand, responsiveness to the launch of new products is necessary for agile supply chain activities that want competitive dominance. To assess whether the service provider has worked optimally and whether the services have met the client's needs (Lagat \& Uyoga, 2019). According to Kahle, Gurel-Atay, Yu, and Ring (2017), information from organizations is also important for customers to make choices and evaluations based on their responsiveness. Responsiveness means that when consumers demand services from service providers and the services offered and the rationalization of the customer are provided, the service is judged favourably and therefore pleased (Lagat \& Uyoga, 2019).

\section{Supply Chain Operational Performance}

Operations related to converting raw materials or intermediate parts into finished goods are also included in the supply chain operations (Loon, Udin, Hassan, Bakar, \& Hanaysha, 2017). The operational performance of the supply chain consists of the operational performance of a company that can help understand product quality and competitiveness in the market (Naway \& Rahmat, 2019). Operational performance is a typical concept that transforms business objectives into strategic corporate capabilities. Fundamentally, the goal of the supply chain is to efficiently deliver goods and services to consumers in a short period, with overall minimum costs and quality (Naway \& Rahmat, 2019). Supply Chain Operational Performance has included supply chain cost, responsiveness, agility, and reliability.

\section{Supply Chain Cost}

Malaysia Industry Manufacturer was developed mainly for export in Malaysia, and competitive success was primarily based on balancing efficiency, culture, cost-effectiveness, and value advantage. The cost of transportation of inventories and harm costs in the supply chain is no lower, while transport or distribution costs are usually the lowest among operating supply chain costs (Visser, Hoefnagels, \& Junginger, 2020). While transport and energy costs continue to rise in today's market environments, efficient control of operations and resources is therefore of paramount importance (Visser et al., 2020). Supply chain costs constitute approximately 55\% of the overall cost of the product. Since the supply chain influence the cost of the finished product, the operations in the supply chain must be regularly strengthened and the overall costs reduced (Visser et al., 2020). The need to remain competitive in the market enables the company to be flexible and adaptable, providing different customer prices (Visser et al., 2020).

\section{Supply Chain Responsiveness}

Supply Chain Responsiveness (SCR) refers to the ability of the supply chain to respond efficiently to consumer demand in a periodic manner (Giannakis, Spanaki, \& Dubey, 2019). Supply Chain Responsiveness was classified into different dimensions: sensitivity to customers, transparency of demand, lead time supply chain response, agility, flexibility, information sharing (Giannakis et al., 2019). From an organization's viewpoint, customer needs are understood, and a high degree of responsiveness is needed to help businesses achieve higher performance (Lee et al., 2017). Moreover, the most significant performance outcome within a supply chain anticipated from upgraded interorganizational relationships is cycle time reduction (Lee et al., 2017). The ability to draw value from responsiveness has proved a key element of the puzzle for politicians who recognize the importance of manufacturing in the local economy and seek to determine which manufacturing offers the best competitiveness in a high-cost economy.

\section{Supply Chain Agility}

While a detailed definition of supply chain agility (SCA) is being established in subsequent parts, a conceptual four working definition is relevant (Gligor, Gligor, Holcomb, \& Bozkurt, 2019). SCA may essentially be defined as the ability of a business to rapidly change its supply chain strategies to respond to or adapt to environmental trends, opportunities, and threats (Gligor et al., 2019). SCA is recognized as a company that seizes, reacts, and uses domestic and external skills for the best satisfaction of its customers' needs (Gligor et al., 2019). In practice, SCA is realized in complexity management through customer efficiency and is represented in SCA downstream operations (Chan, Ngai, \& Moon, 2017; Gligor et al., 2019). With the supply chain partners, SCA can address the market capacity to react immediately to demand breaks. According to Fayezi, Zutshi, and O'Loughlin (2017), supply chain stakeholders must deal with partnership alignment to optimize supply chain efficiency while engaging in agility growth programmes. The enabling influence of 
supply chain practices on the relationship between agile supply chain practices and supply chain effectiveness was investigated (Tarafdar \& Qrunfleh, 2016).

\section{Supply Chain Reliability}

Definitions of the reliability of the supply chain can be classified into two categories: qualitative and quantitative. According to $\mathrm{Wu}$ and Barnes (2018), each supply chain member has an incomplete manufacturing process, which can cause faulty products or even supply interruptions. System reliability is described in the quantitative category as the likelihood that the flow rate from the initial node to the ending node will not be less than in demand (Wu \& Barnes, 2018). In addition, reliability was also described as the portion of faulty products affected by production costs. According to $\mathrm{Wu}$ and Barnes (2018), they used confidential value in collaborative fractal supply chains to evaluate the reliability of supply chain partners. In general, supply chain reliability can be referred to as the perfect order fulfilment of the organizations. This can be determined through delivery item accuracy, delivery time, documents accuracy, and the ideal condition of the delivered item (Lee et al., 2017). The reliability of the supply chain seems to be the supply chain ability regarding the obstacles associated with external or internal system disruptions and before any effort is made to mitigate risk, to continually satisfy end-client demand across the planning horizon (Chen, Xi, \& Jing, 2017).

\section{Underpinning Theory}

Underpinning theory gives justice and help to research that may be a compilation of the thoughts of another writer or full produce. Underpinning in building or reconstruction is the method of strengthening the foundation of an existing or other structure. The Resource-Based View (RBV) implies that a firm must acquire and manage important, unique, inimitable, and non-replaceable (VRIN) resources and capabilities if it is to achieve supply chain operational performance (Cheung et al., 2018). Manufacturing managers have pursued efficiency improvements through adherence to current common paradigms, lean and agile manufacturing, and organizations. Consider that the manufacturing industry is a series of business processes combining desired results with a business process as a whole (Soltan \& Mostafa, 2015). Lean means creating a value stream to dispose of all waste, including energy, whereas agility means using business consciousness and a virtual organization to take advantage of competitive opportunities in a dynamic market (Soltan \& Mostafa, 2015).

\section{Research Framework}

Figure 1 is the theoretical framework for lean and agile practice on supply chain operational performance in the Malaysia manufacturing industry.

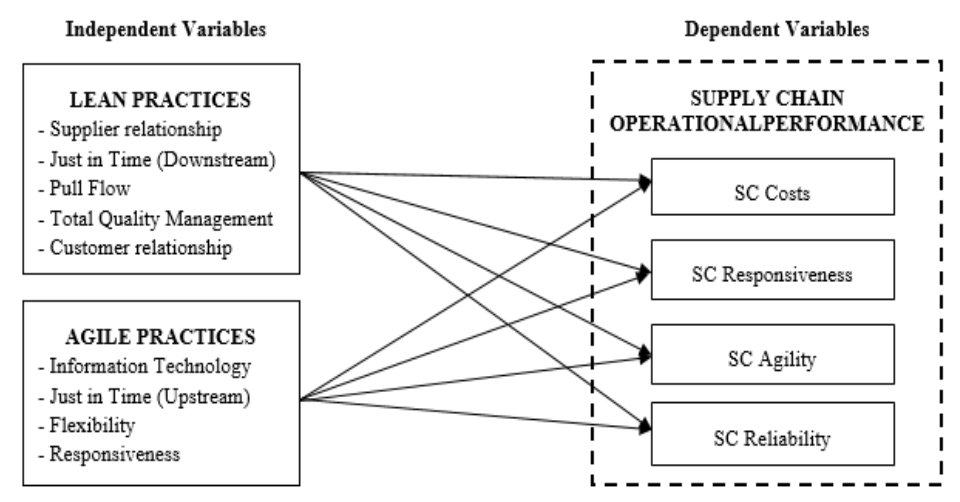

Figure 1. Theoretical framework.

\section{Research Hypothesis}

Supply chain costs are one of the key measures for the operational performance of the supply chain, and any company attempts to provide quality goods as cheaply as possible (Hadrawi, 2019). Cost-effectiveness is one of the main factors for the growth of the supply chain. Inventory expenses account for a significant part of the company's overall costs (Hadrawi, 2019). Development, procurement, and service costs are the most important competitive factors in today's dynamic market (Hadrawi, 2019). According to the consumer, lean detects and removes non-value-added processes or "waste" (Zhou, 2012). Stored, checked, overdue, waiting for products or details, and defects/errors are not added value (Zhou, 2012). Lean is used as a corporate technique for enhancing the quality of service, cutting waste, reducing time and overall costs (Zhou, 2012). The primary goal of a streamlined company is to build a smooth, high-quality operation that can manufacture finished goods and provide services to satisfy consumer demand without waste (Zhou, 2012).

The majority of companies suggested that the key advantages of lean are improved productivity and performance (Zhou, 2012). Lean also increases customer loyalty and reduces production and inventory costs (Zhou, 2012). Given such positioning, cost-effective response to market conditions and consumer needs becomes a key feature of a lean strategy (Iyer et al., 2019). TQM, JIT, Pull Flow in Lean Practices are company changes to the expense of their supply chain; for example, high quality is required at less expense, transport costs reduced, waste reduced (Marodin, Frank, Tortorella, \& Fetterman, 2017; Phan, Nguyen \& Nguyen, 2019). Good relationships with suppliers and consumers can increase supply 
chain costs. Coordinated knowledge sharing, planning, and forecasting have enhanced cost-efficiency capabilities (Iyer et al., 2019). Therefore, it can be concluded that:

H1: Lean practice is positively related to supply chain costs.

A main dynamic attribute that improves the capacity of a business to adapt to the market is lean. Lean refers to the capacity of the company to minimize the cost of production and the distribution of value (Iyer et al., 2019). It represents optimum business process efficiency and is an integral dynamic capability that generates enduring competitive advantage (Iyer et al., 2019). Efficient operations and global cost management related to knowledge, product, and finance flows through the network characterize lean companies (Iyer et al., 2019). Capacity leverages collaboration tools such as expertise and technologies to minimize costs, manufacturing modular products, mass production, specification and optimization of placing orders, strengthened customer service quality, and waste disposal (Iyer et al., 2019). Dedicated and operationally efficient manufacturing infrastructure is built to lean efficiency, which is crucial for providing suitable consumer value in mature markets (Iyer et al., 2019). The lean customer experience capabilities allow businesses to compete strongly in a competitive, cost-conscious market.

In addition, managers responsible for developing market-oriented innovations need to realize that collaboration between them is crucial. Organized schedules, coordinated preparation, preparation, inventory management, and exchanges of knowledge promote lean capacity growth. They increase operational productivity and make reliable predictions of POS data sharing in real-time results in consumer responses and cost savings (Iyer et al., 2019). Enterprises with a learning culture and the capacity to mobilize the resources required are created with improved business sensitivity (Rajagopal, Azar, Bahrin, \& Appasamy, 2016). Indeed, it becomes extremely important for learning-driven supply chain partners to maximize market value development by developing market-sensitive skills and the necessary combinations of relational tools (Rajagopal et al., 2016). Business responsive supply chains are also engaged in the ongoing deployment and optimization of information and services (Schonberger \& Brown, 2017). Learning-driven supply chains investigate developing specific instruments to help collaborators gather the source base (Schonberger \& Brown, 2017). In addition, collaboration operates as a higher resource for enhancing market response by allowing supply chain partners to use and customize services in competitive combinations. Therefore, it assumes that:

H2: Lean practice is positively related to supply chain responsiveness.

According to Khojasteh (2018), supply chain efficiency increases if consumer demand can be modified rapidly while cost reduction is achieved. Moreover, the efficiency of the supply chain also relies on customer loyalty, improvement of quality and cost, delivery speed, the launch of new products, and improved service rates (Khojasteh, 2018). In lean practice, JIT covers the concept of lean production as an integrated socio-technical framework that aims mainly to minimize or eliminate internal waste, both from consumers and suppliers (Inman \& Green, 2018). Considering that JIT is a subset of lean, JIT is a subset of lean concerned primarily with waste disposal by organizational preparation, scheduling, and sequence (Alcaraz et al., 2016). In the supply chain, JIT enhanced agility with reduced transportation costs, fixed cost savings, reduced inventory, reduced overhead distances, reduced lead time generation, reduced process work (WIP), rapid engineering response adjustments, procurement of reduced batch volumes (Alcaraz et al., 2016).

TQM is characterized in various ways in lean practices, as a management theory focused on integrating all levels of organizational functions, continually improving the quality of products and services production, customer satisfaction, and performance measures (Kaur, Singh, \& Singh, 2019). TQM consists of a broad organizational initiative to create an environment that continually enhances customer satisfaction and produces high-quality goods (Kaur et al., 2019). TQM is developed as a critical strategy to improve organizational quality efficiency in the supply chain efficiency of industries (Kaur et al., 2019). TQM seeks to enhance the competitiveness of the global market by reducing costs and increasing the physical and human assets of the enterprise (Kaur et al., 2019). Higher storage capacity pull flow generates substantially higher performance at all levels (Kesen \& Sert, 2019). In the supply chain agility, customer relations may also be improved; processes/activities are a way to build and maintain close and long-lasting customer relations and enhance customer loyalty (Tarafdar \& Qrunfleh, 2016). Therefore, it is believed that:

H3: Lean practice is positively related to supply chain agility.

Buyers reduce the long-term partnership base and invest in relationship processes to improve performance, communication quality, implementation, and innovation (Meena \& Sarmah, 2015). For example, in Malaysia, manufacturers such as Volkswagen, Ford, and GM have worked closely with supply chains to enhance the reliability of a fast-growing country's whole supply chain (Wu \& Barnes, 2018). A reduced partner base may therefore risk disrupting supply to purchasers and all supply chains and increase interdependence. Failure of one group will have a drastic effect on the efficiency of the entire supply chain (Meena \& Sarmah, 2015). Buyers from multiple suppliers may use multiprocurement, contingency procurement, and emergency purchases to improve supply chain flexibility (Meena \& Sarmah, 2015) and to minimize the possibility of damage to the supply chain. For example, there are interruptive risks at any point in a multifaceted supply chain (e.g. raw and semi-product production, operations and maintenance, small and large businesses). 
Nowadays, transport companies face many complicated issues and logistical challenges, particularly the 'Just-in-Time' (JIT) concept, which can solve them. For example, "to attract a greater number of customers, transport companies will first and foremost be concerned with enhancing service efficiency and prestige of the company" (Lukinskiy, Lukinskiy, \& Merkuryev, 2018). The goal of quality is the opportunity to achieve quality consistency (Geyi, Yusuf, Menhat, Abubakar, \& Ogbuke, 2020). Quality covers two aspects: the value of product/service and quality of processes (Geyi et al., 2020). Process quality is important for all competing companies in the industry, as no customer wants defective goods (Geyi et al., 2020). TQM has been thoroughly researched and developed as programs that lead to improving the productivity of the supply chain by focusing on the elimination of all waste from all processes, consumer value criteria, and the development of quality goods and services that accurately meet customer needs (Green, Inman, Sower, \& Zelbst, 2018). It is therefore believed that:

\section{H4: Lean practice is positively related to supply chain reliability.}

Supply chain costs can be defined as costs related to the execution of the supply chain business functions, including acquisitions, manufacturing, and distribution (Arifin, Yanuar, \& Nuryasman, 2018). Conversely, direct prices, advertising, and promotions are not expressed in supply chain costs (Arifin et al., 2018). Nonetheless, operational costs such as overtime and distribution costs are primarily affected by lead times to manufacture products (Arifin et al., 2018). To get goods to the market efficiently and cost-effectively, agile methods need to be implemented. The running costs can be reduced by incorporating new information technology to boost internal communication (Iqbal, Huq, \& Bhutta, 2018). Agile activities of the JIT system are primarily intended to minimize buffer stocks, reduce prices, increase efficiency and boost profitability (García-Alcaraz et al., 2019). JIT's advantages include improved productivity by lowering prices, lowering shipping costs, reducing warehouse costs, and so forth (García-Alcaraz et al., 2019).

Therefore, using agile methods, the cost of doing business will decrease from consumer price reduction (Jermsittiparsert, Sutduean, Sriyakul, \& Khumboon, 2019). From the viewpoint of new product growth, the gain will significantly reduce time, customer satisfaction, and quality control problems, including promoting the new product (Jermsittiparsert et al., 2019). Supply management is the company's ability to satisfy customer expectations as product flows are handled (Haq, Hameed, \& Raheem, 2020). In comparison, the versatility of products is designed to launch new products or upgrade existing products according to the current demand without significant impacts on the cost and supply chain (Haq et al., 2020). The costs of measuring performance above responsiveness are overlooked by manufacturers who have little contact with final consumers (Schonberger \& Brown, 2017). As a result, efforts to improve productivity tend to be limited to the pursuit of efficiency within the factory: quick internal movement, smooth schedules, and high power utilization (Schonberger \& Brown, 2017). It is therefore believed that:

H5: Agile Practices is positively related to supply chain costs.

Operational flexibility is emphasized, and businesses are faced with the task of delivering a planned product/service following unexpected consumer demand shifts (Geyi et al., 2020). Flexibility means that goods or production processes may be quickly altered (Geyi et al., 2020). In a previous report, supply chain flexibility was either efficiency-related or versatile (Cheung et al., 2018). Effective capabilities enable improved logistics efficiency at a lower cost. In contrast, flexible capabilities allow companies to maintain relations with supply chain partners while being responsive to customer demands at the same time (Cheung et al., 2018). The Just in Time (JIT) method, established at the end of the supply chain to deal with dealer stock issues, is becoming increasingly relevant (Tseng, Wee, Reong, \& Wu, 2019). Therefore, by addressing the problem of delivery stock during the end of the supply chain, the Just in Time (JIT) approach has forged ahead of the others (Tseng et al., 2019).

Agile approaches to designing information systems, including Scrum, Intense Programming, and Crystal, allegedly provide ways to make the team more agile to meet evolving demands and satisfy them (Recker et al., 2017). Comprehensive reaction determines the length, scope, or range of customer inquiries response software teams, and the response effectiveness is the time, cost, energy, or effort involved in the reactions of software teams (Recker et al., 2017). The successful implementation of information systems depends primarily on customer demands in product delivery (Recker et al., 2017). However, an agile approach uses consumer intelligence to seize opportunities and rapidly satisfy customer needs in a volatile supply chain (Fayezi et al., 2017). It improves solid efficiency by improving rapid transition capabilities in a changing world to meet consumer needs (Gligor, Esmark, \& Holcomb, 2015). If there is a comprehensive response to consumer demand changes, then specific and thorough information on how the specifications turn into software features is included (Recker et al., 2017). In addition, this will contribute to improved customer loyalty. It is therefore believed that:

H6: Agile practice is positively related to supply chain responsiveness.

Supply chain agility is critical for a targeted company to execute based on varying customer needs. The company can implement agile activities that adapt rapidly to dynamic demand and short product life cycles (Tarafdar \& Qrunfleh, 2016). The agile practice focuses on individuals, technologies, and procedures when engaging with consumers and responding to change to exploit incentives (Geyi et al., 2020). This business model helps businesses leverage competitive opportunities in a dynamic market through industry awareness and alliances (Geyi et al., 2020). The definition has been 
expanded beyond the company's borders to include the supply chain market, demonstrating the need for strategic alliances, knowledge exchanges, information sharing, coordination of resource resources, and effective supply chain leadership.

The definition consists of a strategic willingness to meet changing business criteria to reduce costs and increase customer loyalty (Leite \& Braz, 2016). This ensures that the company is in line with the requirements of an ever-changing - dynamic or unpredictable world and its ability to benefit from these changes (Leite \& Braz, 2016). Agile manufacturing concepts are related to a business approach that focuses on value-added to attract consumers in highly customized goods and high quality (Leite \& Braz, 2016). They include versatile processes, the speed of reaction of manufacturers, a shortened product life cycle, company collaboration across the supply chain, high-tech and highly skilled workers usage (Leite \& Braz, 2016). Agile development is a core concept for internal and external collaboration and the area of adjustment and confusion (Leite \& Braz, 2016). There is a positive association between the agile approach to development and differentiation and a negative correlation between the same theory and the cost control approach (Leite \& Braz, 2016). It is therefore believed that:

H7: Agile practice is positively related to supply chain agility.

In the view of agile supply chains, the reliability of the supply partners is critical as they are vulnerable to the failure of the supplier to meet the high response and flexibility requirements that result in the disruption of the entire network (Wu \& Barnes, 2018). To minimize the risk of disruption and improve the reliability of the operational performance of the supply chain, policymakers must pay more attention to the design and role of the supply chain, taking into account the decision of the procurement strategy (Wu \& Barnes, 2018). To meet the growing demand by introducing new products, timely access to market trends, knowledge, customer expectations, and competitive action is required (Tarafdar \& Qrunfleh, 2016). Secondly, knowledge is necessary to develop and execute those goods rapidly and efficiently conduct inter-company processes in cooperation and collaboration with partners, including timely sharing of plans, lead times, and stock (Wagner, Grosse-Ruyken, \& Erhun, 2018). Such requirements can be discussed in the portfolio of IS applications, which should have market research and understanding capabilities and inter-organizational knowledge exchange, cooperation, and teamwork (Recker et al., 2017). It is therefore believed that:

H8: Agile practice is positively related to supply chain reliability.

\section{METHODOLOGY}

In this analysis, quantitative approaches were used where the effects of statistical data were evaluated. First, this study began with the production and pre-test measurements of the testing method and the study. Therefore, it is important to carry out data collection and data analysis steps to analyse the relationship between variables. In addition, this analysis uses a cross-sectional approach. To achieve the objective, a closed-ended questionnaire was used for data collection purposes. The five-point interval Likert scale was chosen to measure the instrument, from 1 (strongly disagree) to 5 (strongly agree). This research used it to measure lean practices, agile practices, and supply chain operational performance. The minimum sample size of G-power statistical analysis software is 107, while the targeted populations were the Malaysian manufacturing companies with 3262 listed in FMM Directory (2019). This study sent 550 sets of questionnaires and received a total of 112 responses with $20.36 \%$ of the response rate.

After that, Smart-PLS 3 software was used to analyze the data. Three assessments were conducted, which are normality, measurement model, and structural model assessment. Normality testing is very important because it is decided based on normality status, central tendency measurements, dispersion, and selection of parametric/nonparametric tests (Hult et al., 2018). Convergence and discriminatory validity were identified in the evaluation of the measurement model. For the convergent validity test, the value of outer loading, AVE, CR was used for interpretation. The measurement model is a modified path model because it needs to accept factor loading, which needs to be more than 0.5, AVE which needs to be more than 0.5, and CR, which requires more than 0.7 (Hair, Black, Babib, \& Anderso, 2010). Then, discriminant validity was conducted by referring to Fornell- Larcker. The structural model describes the structural paths between the constructions, while the measurement models represent the relationship between construction and related indicators (Hult et al., 2018). Therefore, there were eight hypotheses tested. The hypotheses of this study were tested using a one-tailed test with a 0.05 confidence level. The 500 -sample bootstrap model at a confidence level of 0.05 was checked using the Smart-PLS 3 software.

\section{RESULT AND FINDINGS}

\section{Demographic Profile- Companies}

Based on Table 1, the first demographic item is company types. The highest number of respondents are from other companies with 30 respondents and the lowest number of respondents from Garments Company with 6 respondents $(5.36 \%)$. Furthermore, the second demography item is the nature of the company's ownership. The nature of company ownership in government consists of 22 responses which obtain $19.64 \%$ of the whole responses. The remaining percentage goes through the private sector, which has 90 responses with $80.36 \%$. 
Moreover, the scope of company operation has four categories: International, Local (state), National, and Regional. International categories responses in this statistical analysis consist of the highest number of 42 persons $(37.5 \%)$, and the lowest number going to the region have 12 persons $(10.71 \%)$. The number of employees who have responses shows that the highest response rate is less than 100 categories, and the lowest response rate is the employee with 500-900 persons. These categories only have nine responses which occupy $8.04 \%$ for the existence period of the company. Categories that obtain the highest responses with 60 persons are over 20 years and occupy $53.57 \%$, and the lowest response rate is less than five years with nine persons $(8.04 \%)$.

Table 1. Company profile.

\begin{tabular}{|c|c|c|}
\hline Demographic Items & Count & Percentage $(\%)$ \\
\hline \multicolumn{3}{|l|}{ Types of company } \\
\hline Textiles & 7 & $6.25 \%$ \\
\hline Mobile & 8 & $7.14 \%$ \\
\hline Electronic & 25 & $22.32 \%$ \\
\hline Garments & 6 & $5.36 \%$ \\
\hline Metal \& metal products & 12 & $10.71 \%$ \\
\hline Machinery & 10 & $8.93 \%$ \\
\hline Food & 14 & $12.50 \%$ \\
\hline Others & 30 & $26.75 \%$ \\
\hline Adhesive & 1 & $0.89 \%$ \\
\hline Assembly wire harness & 1 & $0.89 \%$ \\
\hline Automotive & 2 & $1.79 \%$ \\
\hline Banner & 1 & $0.89 \%$ \\
\hline Beverage & 1 & $0.89 \%$ \\
\hline Book & 1 & $0.89 \%$ \\
\hline Building material & 1 & $0.89 \%$ \\
\hline Cable Support System & 1 & $0.89 \%$ \\
\hline Cosmetic & 1 & $0.89 \%$ \\
\hline Measuring and Analytical Instruments & 1 & $0.89 \%$ \\
\hline Medical and industrial gases & 1 & $0.89 \%$ \\
\hline Nonwoven & 1 & $0.89 \%$ \\
\hline Office Furniture & 3 & $2.68 \%$ \\
\hline Painting, fabrication of extrusion, panel, angle & 1 & $0.89 \%$ \\
\hline Paper, paper box and paper packaging & 3 & $2.68 \%$ \\
\hline pewterware & 1 & $0.89 \%$ \\
\hline Plastic and Rubber & 6 & $5.36 \%$ \\
\hline Precast manhole & 1 & $0.89 \%$ \\
\hline Tent \& membrane industries & 1 & $0.89 \%$ \\
\hline Wooden floor & 1 & $0.89 \%$ \\
\hline \multicolumn{3}{|l|}{ Nature of company's ownership } \\
\hline Government & 22 & $19.64 \%$ \\
\hline Private & 90 & $80.36 \%$ \\
\hline \multicolumn{3}{|l|}{ Scope of company operation } \\
\hline International & 42 & $37.50 \%$ \\
\hline Local (State) & 41 & $36.61 \%$ \\
\hline National & 17 & $15.18 \%$ \\
\hline Regional & 12 & $10.71 \%$ \\
\hline \multicolumn{3}{|l|}{ Amount of employees in the company } \\
\hline Less than 100 & 43 & $38.39 \%$ \\
\hline 100 to 499 & 42 & $37.50 \%$ \\
\hline 500 to 999 & 9 & $8.04 \%$ \\
\hline Over 1000 & 18 & $16.07 \%$ \\
\hline
\end{tabular}




\begin{tabular}{lcc}
\hline Demographic Items & Count & Percentage (\%) \\
\hline Existence period of the company & & \\
Less than 5 years & 9 & $8.04 \%$ \\
6 to 10 years & 18 & $16.07 \%$ \\
11 to 15 years & 14 & $12.50 \%$ \\
16 to 20 years & 11 & $9.82 \%$ \\
Over 20 years & 60 & $53.57 \%$ \\
\hline Total & $\mathbf{1 1 2}$ & $\mathbf{1 0 0 . 0 0 \%}$ \\
\hline
\end{tabular}

\section{Demographic Profile- Respondents}

Based on Table 2, it showed the profile of respondents. Firstly, the demographic item is gender, and it consists of females and males. Male categories have the highest number than the female with 71 respondents (63.9\%), and the female has 41 respondents $(36.61 \%)$. Besides, in terms of working in this industry, categories 6 to 10 years have the highest number. There are 34 respondents, occupying $30.36 \%$, and the lowest number in this section is less than one year, consisting of 3 respondents only and occupying $2.68 \%$. Regarding company designation, the highest number of designations is department manager 25 respondents $(22.32 \%)$ and the lowest number of designation engineer one respondent $(0.89 \%)$. Lastly, in terms of education level, the categories that obtain the highest responses are Bachelor's Degree, 68 respondents (60.71\%), and the Associate's Degree is the lowest number categories. There are six respondents (5.36\%).

Table 2. Respondents demographic.

\begin{tabular}{|c|c|c|}
\hline Demographic Items & Count & Percentage $(\%)$ \\
\hline \multicolumn{3}{|l|}{ Gender } \\
\hline Male & 71 & $63.39 \%$ \\
\hline Female & 41 & $36.61 \%$ \\
\hline \multicolumn{3}{|l|}{ Years of working } \\
\hline Less than 1 year & 3 & $2.68 \%$ \\
\hline 2 to 5 years & 31 & $27.68 \%$ \\
\hline 6 to 10 years & 34 & $30.36 \%$ \\
\hline 11 to 15 years & 14 & $12.50 \%$ \\
\hline 16 to 20 years & 12 & $10.71 \%$ \\
\hline More than 20 years & 18 & $16.07 \%$ \\
\hline \multicolumn{3}{|l|}{ Designation of company } \\
\hline Vice President or Above & 5 & $4.46 \%$ \\
\hline Managing Director & 3 & $2.68 \%$ \\
\hline Director & 9 & $8.04 \%$ \\
\hline General Manager & 21 & $18.75 \%$ \\
\hline Senior Manager & 14 & $12.50 \%$ \\
\hline Department Manager & 25 & $22.32 \%$ \\
\hline Executive & 24 & $21.43 \%$ \\
\hline Officer & 5 & $4.46 \%$ \\
\hline \multicolumn{3}{|l|}{ Other: } \\
\hline Analyst & 3 & $2.68 \%$ \\
\hline Engineer & 1 & $0.89 \%$ \\
\hline Plant Manager & 2 & $1.79 \%$ \\
\hline \multicolumn{3}{|l|}{ Education Level } \\
\hline Doctor Degree or Beyond & 0 & $0 \%$ \\
\hline Master's or Specialist's Degree & 23 & $20.54 \%$ \\
\hline Bachelor's Degree & 68 & $60.71 \%$ \\
\hline Associate's Degree & 6 & $5.36 \%$ \\
\hline Technical School Certification & 10 & $8.93 \%$ \\
\hline High School or Equivalent & 5 & $4.46 \%$ \\
\hline
\end{tabular}




\begin{tabular}{lcc}
\hline Demographic Items & Count & Percentage (\%) \\
\hline Total & 112 & $100 \%$ \\
\hline
\end{tabular}

\section{Descriptive Statistics and Normality Assessment}

Descriptive statistics are considered important to judge the general state of Malaysia's manufacturing industry concerned with lean practices, agile practices, and supply chain operational performance. The mean value in this study is used to describe the central tendency of lean practices, agile practices, and supply chain operational performance. The standard deviation is a more reliable and thorough measure of dispersion since the outlier will significantly exaggerate the range. Based on the details in Appendix 4, the descriptive statistics clarify the mean value of lean practices between 3.81 and 4.49 with a range of standard deviations between 0.59 and 0.91 . Furthermore, for agile practices, the descriptive statistics explain the mean value is between 3.89 and 4.36 with the range of standard deviation between 0.66 and 0.95 . Besides that, the dependent variable supply chain operational performance, the descriptive statistics explain the mean value between 3.96 and 4.54 with the range of standard deviation between 0.60 and 0.65 .

For the normality assessment, in the case of a normality assessment, if the skewness is less than-1 or greater than 1 , the distribution is strongly distorted. If the skewness is between- 1 and- 0.5 or between 0.5 and 1 , the distribution shall be moderately distorted. If the skewness is between- 0.5 and 0.5 , the distribution is roughly symmetrical. Kurtosis is acceptable in the range of -10 to +10 when using SEM (Schneider \& Wheeler-Kingshott, 2014). The range of kurtosis statistics for lean practices is between -0.23 to 2.66 , with the range of skewness -1.27 to -0.39 . The kurtosis statistics and skewness range for agile practices are between -0.58 to 4.00 and -1.39 to -0.53 . The kurtosis statistics and skewness range for supply chain operational performance is between -0.15 to 2.22 and -1.20 to -0.60 . Therefore, all the skewness values are highly skewed, and the kurtosis value is considered a normal distribution. Table 3 shows the table of descriptive statistics and normality assessment which is the average of each item.

Table 3. Descriptive statistics and normality assessment.

\begin{tabular}{lcccccc}
\hline \multirow{2}{*}{ Construct } & \multicolumn{3}{c}{ Descriptive Statistics } & \multicolumn{3}{c}{ Normality Statistics } \\
\cline { 2 - 7 } & Min & Max & Mean & $\begin{array}{c}\text { Standard } \\
\text { Deviation }\end{array}$ & $\begin{array}{c}\text { Excess } \\
\text { Kurtosis }\end{array}$ & Skewness \\
\hline Supply Chain Reliability (SCRT) & 2 & 5 & 4.407 & 0.637 & 0.754 & -0.841 \\
Supply Chain Responsiveness (SCRS) & 1 & 5 & 4.301 & 0.714 & 1.006 & -0.959 \\
Supply Chain Agility (SCA) & 1 & 5 & 4.281 & 0.707 & 1.316 & -0.940 \\
Supply Chain Cost (SCC) & 2 & 5 & 4.245 & 0.774 & 0.359 & -0.856 \\
Supplier Relationship (SR) & 2 & 5 & 4.347 & 0.690 & 1.030 & -0.962 \\
Just in Time in lean (LJIT) & 1 & 5 & 4.163 & 0.756 & 0.269 & -0.672 \\
Pull Flow (PF) & 1 & 5 & 3.953 & 0.794 & 0.847 & -0.822 \\
Total Quality Management (TQM) & 2 & 5 & 4.338 & 0.661 & 0.869 & -0.812 \\
Customer Relationship (CR) & 2 & 5 & 4.247 & 0.748 & 1.012 & -0.946 \\
Information Technology (IT) & 2 & 5 & 4.174 & 0.788 & 0.283 & -0.777 \\
Just in Time in agile (AJIT) & 1 & 5 & 4.085 & 0.815 & 0.224 & -0.736 \\
Flexibility (FLX) & 1 & 5 & 4.246 & 0.747 & 0.797 & -0.843 \\
Responsiveness (RESP) & 1 & 5 & 4.278 & 0.732 & 1.321 & -0.981 \\
\hline
\end{tabular}

\section{Assessment of Measurement Model}

A total of 112 usable responses were used for analysis using a partial least square structural equation modelling (PLSSEM) analytical technique using SmartPLS. Based on Figure 2, there are many dimensions of independent variables; its implementation allows researchers to change the abstraction of predictor and outcome variables and decreases the complexity of the model (Schuberth, Rademaker, \& Henseler, 2020). This increases the parsimony of a model by calculating fewer parameters (Schuberth et al., 2020). In essence, the first method calculates the second-order factors by using the variables measurable from all the factors of the first order (Duarte \& Amaro, 2018). While there are usually many abstraction levels, in empirical studies, second-order models prevail (Schuberth et al., 2020). The second-order model is displayed in the latent variables named LP and AP. LP is lean practices, and AP is agile practices; there consists of all the variable items, and all of these are called second-order models. Each manifest is considered important for individual item reliability if its loading value is greater than 0.5 (Rahman, Al-Emad, \& Nagapan, 2016). In this analysis, however, the loading value is less than 0.5 , it will be removed and abandoned. Hence, this study will use the modified path model as shown in Figure 2 to conduct convergent and discriminant validity. 


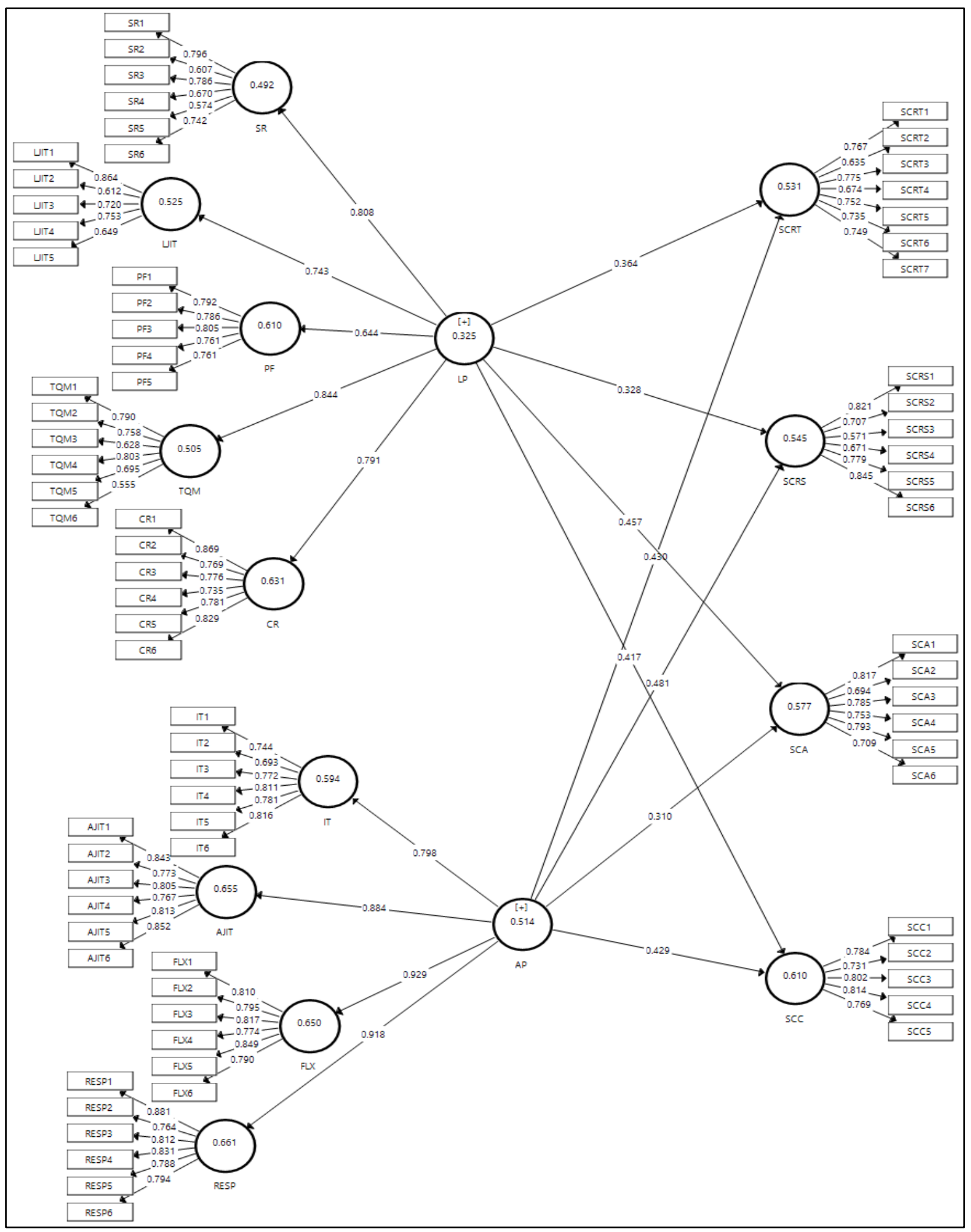

Figure 2. Modified PLS Path Model.

\section{Convergent Validity}

As Hair et al. (2010) recommended, the accepted threshold value for factor loading is 0.40 and above. The value of composite reliability (CR) above 0.70 is considered sufficient, and the value of the average extracted variance (AVE) above 0.50 is deemed to be reasonable. The model is calculated without the second-order constructs to obtain the construct score for the first-order constructs. Technically, after removing the second-order constructs, researchers can use any structural model specification involving the remaining constructs to get the construct score. Table 4 represents convergent validity, including outer loading, average variance extracted (AVE), composite reliability (CR), and Cronbach's Alpha. Based on Table 4, all of the values of outer loading are exceeding 0.5. All of the AVE values are 0.50 and above, and the CRs of all the latent variables exceeded 0.70 . It means all latent constructs' reliability are acceptable. In this study, latent variables of lean practices and agile practices will be using the second-order model so will the repeated indicators approach. However, the AVE and CR calculator will be used to calculate the AVE and CR. Moreover, the value of AVE and CR in lean practices and agile practices are acceptable, which exceeded 0.5 and 0.7 . Lastly, SCRT2, SCRT4, SCRT6, 
SCRS3, SCRS4, SR2, LJIT2, TQM6, IT2, FLX2, FLX4, FLX6, RESP2, RESP6 were deleted due to the weakest item in construct to increase the discriminant validity.

Table 4. Convergent Validity.

\begin{tabular}{|c|c|c|c|c|c|c|}
\hline Construct & Item code & Item & $\begin{array}{l}\text { Outer } \\
\text { Loading }\end{array}$ & AVE & $\mathrm{CR}$ & $\begin{array}{l}\text { Cronbach's } \\
\text { Alpha }\end{array}$ \\
\hline \multirow[t]{4}{*}{ SCRT } & SCRT1 & customer service level. & 0.807 & 0.636 & 0.875 & 0.809 \\
\hline & SCRT3 & delivering quality products to customers. & 0.825 & & & \\
\hline & SCRT5 & $\begin{array}{l}\text { providing accurate information to } \\
\text { members in the supply chain. }\end{array}$ & 0.779 & & & \\
\hline & SCRT7 & $\begin{array}{l}\text { providing adequate information to } \\
\text { members in the supply chain. }\end{array}$ & 0.778 & & & \\
\hline \multirow[t]{4}{*}{ SCRS } & SCRS1 & responding to supplier or customer. & 0.835 & 0.661 & 0.886 & 0.828 \\
\hline & SCRS2 & timely delivery. & 0.754 & & & \\
\hline & SCRS5 & delivery emergency orders. & 0.782 & & & \\
\hline & SCRS6 & delivery lead time. & 0.875 & & & \\
\hline \multirow[t]{6}{*}{ SCA } & SCA1 & adaption to product volume changes. & 0.816 & 0.577 & 0.891 & 0.853 \\
\hline & SCA2 & solve unexpected problems. & 0.698 & & & \\
\hline & SCA3 & $\begin{array}{l}\text { resources relocation to support demand } \\
\text { changes. }\end{array}$ & 0.786 & & & \\
\hline & $\mathrm{SCA} 4$ & customization level. & 0.750 & & & \\
\hline & SCA5 & speed of response to demand changes. & 0.792 & & & \\
\hline & SCA6 & expedite shipments. & 0.709 & & & \\
\hline \multirow[t]{5}{*}{$\mathrm{SCC}$} & $\mathrm{SCC} 1$ & customer service level. & 0.784 & 0.610 & 0.886 & 0.840 \\
\hline & $\mathrm{SCC} 2$ & speeding of new products introduction. & 0.731 & & & \\
\hline & $\mathrm{SCC} 3$ & delivering quality products to customers. & 0.802 & & & \\
\hline & $\mathrm{SCC} 4$ & responding to urgent customer request. & 0.815 & & & \\
\hline & SCC5 & $\begin{array}{l}\text { providing accurate information to } \\
\text { members in the supply chain. }\end{array}$ & 0.769 & & & \\
\hline \multirow[t]{5}{*}{ SR } & SR1 & $\begin{array}{l}\text { we work closely with our suppliers when } \\
\text { developing our offerings. }\end{array}$ & 0.796 & 0.538 & 0.852 & 0.784 \\
\hline & SR3 & $\begin{array}{l}\text { we strive to establish long-term } \\
\text { relationships with our suppliers. }\end{array}$ & 0.801 & & & \\
\hline & SR4 & $\begin{array}{l}\text { we work closely together with our } \\
\text { suppliers and offer support to solve any } \\
\text { problematic issues. }\end{array}$ & 0.691 & & & \\
\hline & SR5 & $\begin{array}{l}\text { we give our suppliers feedback on quality } \\
\text { and delivery performance. }\end{array}$ & 0.592 & & & \\
\hline & SR6 & $\begin{array}{l}\text { our company has a formal system in place } \\
\text { to assess the profit and cost associated } \\
\text { with existing supplier relationships. }\end{array}$ & 0.767 & & & \\
\hline \multirow[t]{3}{*}{ LJIT } & LJIT1 & $\begin{array}{l}\text { our customers receive just-in-time } \\
\text { deliveries from us. }\end{array}$ & 0.861 & 0.588 & 0.850 & 0.766 \\
\hline & LJIT3 & $\begin{array}{l}\text { we always deliver on time to our } \\
\text { customers. }\end{array}$ & 0.745 & & & \\
\hline & LJIT4 & $\begin{array}{l}\text { our customers are linked with us via JIT } \\
\text { systems. }\end{array}$ & 0.781 & & & \\
\hline
\end{tabular}




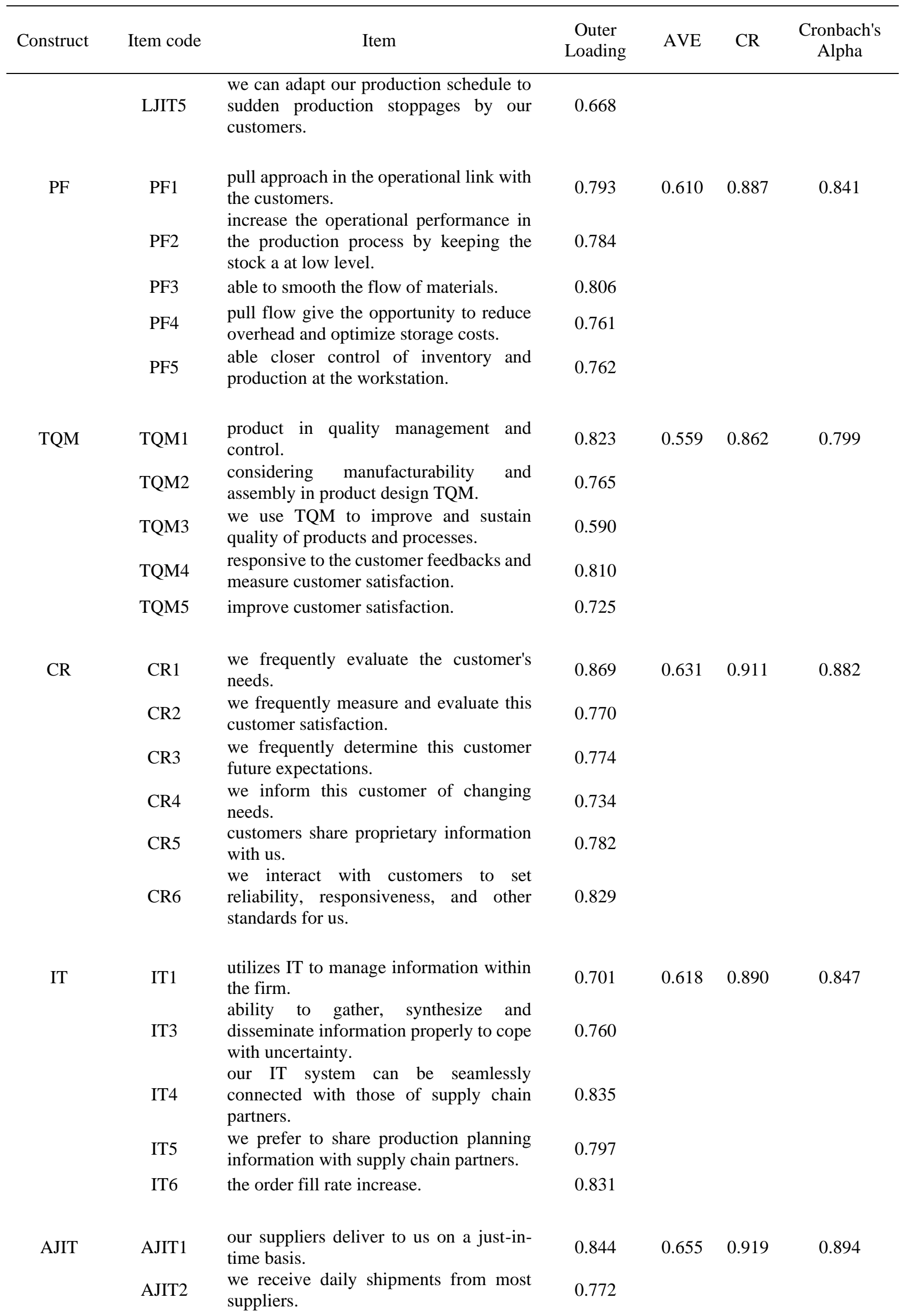




\begin{tabular}{|c|c|c|c|c|c|c|}
\hline Construct & Item code & Item & $\begin{array}{l}\text { Outer } \\
\text { Loading }\end{array}$ & AVE & CR & $\begin{array}{l}\text { Cronbach's } \\
\text { Alpha }\end{array}$ \\
\hline & AJIT3 & $\begin{array}{l}\text { suppliers fill our Kanban containers, } \\
\text { rather than filling purchase orders. }\end{array}$ & 0.806 & & & \\
\hline & AJIT4 & $\begin{array}{l}\text { we can depend upon on-time delivery } \\
\text { from our suppliers. }\end{array}$ & 0.767 & & & \\
\hline & AJIT5 & $\begin{array}{l}\text { our suppliers are linked with us by a pull } \\
\text { system. }\end{array}$ & 0.812 & & & \\
\hline & AJIT6 & $\begin{array}{l}\text { suppliers frequently deliver materials to } \\
\text { us. }\end{array}$ & 0.852 & & & \\
\hline \multirow[t]{3}{*}{ FLX } & FLX1 & $\begin{array}{l}\text { we able to introduce new products into } \\
\text { production quickly. }\end{array}$ & 0.864 & 0.756 & 0.903 & 0.839 \\
\hline & FLX3 & $\begin{array}{l}\text { we able to make design changes in the } \\
\text { product after production has started. }\end{array}$ & 0.873 & & & \\
\hline & FLX5 & $\begin{array}{l}\text { we able to efficiently alter delivery } \\
\text { schedules to meet customer requirements } \\
\text { in conjunction with this supplier. }\end{array}$ & 0.871 & & & \\
\hline \multirow[t]{4}{*}{ RESP } & RESP1 & $\begin{array}{l}\text { we able to introduce new products into } \\
\text { production quickly. }\end{array}$ & 0.886 & 0.723 & 0.912 & 0.872 \\
\hline & RESP3 & we able to increase on-time delivery rate. & 0.848 & & & \\
\hline & RESP4 & $\begin{array}{l}\text { we able to increase the frequencies of } \\
\text { new product introductions. }\end{array}$ & 0.839 & & & \\
\hline & RESP5 & $\begin{array}{l}\text { we able to speed up improving customer } \\
\text { service. }\end{array}$ & 0.826 & & & \\
\hline
\end{tabular}

Note: $\mathrm{AVE}=$ average variance extracted; $\mathrm{CR}=$ composite reliability; Loadings $>0.50 ; \mathrm{AVE}>0.50$; Composite reliability > 0.70; SCRT2, SCRT4, SCRT6, SCRS3, SCRS4, SR2, LJIT2, TQM6, IT2, FLX2, FLX4, FLX6, RESP2, RESP6 were deleted due to weakest item in construct to increase the discriminant validity.

\section{Discriminant Validity}

According to the suggestion of Henseler et al. (2015), the HTMT value exceeding 0.90 is a lack of discriminant validity. Since some HTMT values exceed 0.9, therefore, this study decided to use Fornell-Larcker as a criterion. Based on Table 5, all square roots of AVE values are higher than the correlation estimates between these variables and other latent variables. As a consequence, these imply an acceptable discriminatory validity.

Table 5. Discriminant Validity: Fornell-Larcker Criterion.

\begin{tabular}{llllllllllllll}
\hline & AJIT & CR & FLX & IT & LJIT & PF & RESP & SCA & SCC & SCRS & SCRT & SR & TQM \\
\hline AJIT & 0.809 & & & & & & & & & & & & \\
CR & 0.419 & 0.794 & & & & & & & & & & & \\
FLX & 0.683 & 0.575 & 0.869 & & & & & & & & & & \\
IT & 0.738 & 0.419 & 0.628 & 0.786 & & & & & & & & & \\
LJIT & 0.746 & 0.416 & 0.647 & 0.629 & 0.767 & & & & & & & & \\
PF & 0.346 & 0.401 & 0.283 & 0.386 & 0.393 & 0.781 & & & & & & & \\
RESP & 0.682 & 0.584 & 0.839 & 0.623 & 0.659 & 0.352 & 0.850 & & & & & & \\
SCA & 0.496 & 0.542 & 0.624 & 0.476 & 0.603 & 0.354 & 0.684 & 0.760 & & & & & \\
SCC & 0.674 & 0.573 & 0.680 & 0.564 & 0.627 & 0.453 & 0.705 & 0.636 & 0.781 & & & & \\
SCRS & 0.591 & 0.448 & 0.639 & 0.541 & 0.620 & 0.330 & 0.719 & 0.726 & 0.754 & 0.813 & & & \\
SCRT & 0.506 & 0.473 & 0.629 & 0.476 & 0.497 & 0.341 & 0.673 & 0.615 & 0.657 & 0.764 & 0.798 & & \\
SR & 0.440 & 0.531 & 0.589 & 0.449 & 0.453 & 0.389 & 0.551 & 0.591 & 0.616 & 0.598 & 0.592 & 0.734 & \\
TQM & 0.615 & 0.534 & 0.623 & 0.546 & 0.614 & 0.432 & 0.655 & 0.578 & 0.626 & 0.648 & 0.618 & 0.602 & 0.747 \\
\hline
\end{tabular}

Note: Diagonal values are square-root of AVE, off-diagonal values are correlation coefficients. 


\section{Hypotheses Testing}

In this study, there are a total of eight hypotheses. Therefore, there will be eight hypotheses to be tested. The SmartPLS 3 bootstrapping was used to test these hypotheses. The hypotheses of this analysis were based on a single-tailed test with a confidence level of 0.05 . The 500-sample bootstrap model at a confidence level of 0.05 was checked using the Smart-PLS 3 program. The hypotheses tested in this analysis are shown in Table 6 based on the path coefficient ( $($ ) and the importance of this model. To assess statistical significance, the t-value must exceed 1.65, while the p-value must be not more than 0.05 to achieve the level of acceptance (Hult et al., 2018). Based on Table 6, the t-value of H1 to H8 are exceeded 1.65, and all the hypotheses considered significant. For the p-value, all hypotheses do not exceed 0.05 ; thus, all the hypotheses are supported. Subsequently, the hypotheses were checked after transforming the measurement model to a structural model and setting it up for bootstrapping.

Table 6. Result of hypotheses testing.

\begin{tabular}{|c|c|c|c|c|c|c|c|c|c|}
\hline \multirow{2}{*}{$\begin{array}{l}\text { Hypo- } \\
\text { theses }\end{array}$} & \multirow{2}{*}{ Path } & \multirow{2}{*}{$\begin{array}{l}\text { Std. } \\
\text { Beta }\end{array}$} & \multirow{2}{*}{$\begin{array}{l}\text { Std. } \\
\text { Devia- } \\
\text { tion }\end{array}$} & \multirow{2}{*}{$\begin{array}{l}\mathrm{T}- \\
\text { Values }\end{array}$} & \multirow{2}{*}{$\begin{array}{l}\text { P- } \\
\text { Values }\end{array}$} & \multirow{2}{*}{ Bias } & \multicolumn{2}{|c|}{ Confidence Interval } & \multirow{2}{*}{ Decision } \\
\hline & & & & & & & $5 \%$ & $95 \%$ & \\
\hline H1 & AP -> SCA & 0.239 & 0.102 & 2.345 & 0.010 & 0.002 & 0.079 & 0.406 & Supported \\
\hline $\mathrm{H} 2$ & AP -> SCC & 0.395 & 0.103 & 3.837 & 0.000 & 0.012 & 0.207 & 0.548 & Supported \\
\hline H3 & AP -> SCRS & 0.424 & 0.117 & 3.620 & 0.000 & 0.009 & 0.216 & 0.604 & Supported \\
\hline $\mathrm{H} 4$ & AP $->$ SCRT & 0.318 & 0.111 & 2.868 & 0.002 & 0.002 & 0.126 & 0.486 & Supported \\
\hline H5 & LP -> SCA & 0.517 & 0.118 & 4.386 & 0.000 & 0.007 & 0.287 & 0.677 & Supported \\
\hline H6 & LP -> SCC & 0.452 & 0.106 & 4.278 & 0.000 & -0.009 & 0.263 & 0.629 & Supported \\
\hline $\mathrm{H} 7$ & LP -> SCRS & 0.362 & 0.115 & 3.141 & 0.001 & -0.002 & 0.173 & 0.539 & Supported \\
\hline H8 & LP -> SCRT & 0.418 & 0.121 & 3.469 & 0.000 & -0.003 & 0.201 & 0.608 & Supported \\
\hline
\end{tabular}

Note: $>$ t-value $=(\mathrm{p}$-value $):>1.645(\mathrm{p}<0.05)$

\section{DISCUSSION}

This study investigates the effect of lean practices and analyses the effect of agile practices on supply chain operational performance in the Malaysia manufacturing industry. Eight hypotheses were analyzed. The findings of the analysis are based on the online questionnaire and the Smart-PLS bootstrapping. This study predicts that the first hypothesis is a positive relationship between lean practices and the supply chain cost in the Malaysian manufacturing industry. This is because lean tools and techniques can minimize costs, increase sales, and improve the quality and efficiency of goods (Liu, Niu, \& Li, 2018). In addition, the second hypothesis is that there is a positive relationship between Lean practices and responsiveness of the supply chain in the Malaysian manufacturing industry. The findings of this study revealed that lean practices could strengthen the capacity of businesses to adapt and achieve responsiveness in the supply chain environment (Hernandez-Matias, Ocampo, Hidalgo, \& Vizan, 2019). The analysis of the third hypothesis shows that the Lean practices have been proven to dramatically boost supply chain agility in the Malaysian manufacturing industry (Omwoyo, Wanyoike, \& Mbeche, 2019). Moreover, the fourth hypothesis explains that the Lean methods can help ensure supply chain efficiency, such as meeting the customer requirements at the right time, right quantity, and expected quality (Zhang et al., 2020).

In addition, the result of the fifth hypothesis revealed that agile speed-up methods promote waste reduction, while materials invest less time in inventory, minimizing running costs (Geyi et al., 2020). This study further found that agile approaches have a collective knowledge that improves the capacity of companies to adapt to changes in their operating environment (Recker et al., 2017) in the analysis of the sixth hypothesis. In addition, agile methods introducing new goods to turbulent and unpredictable markets in terms of dynamic and varied demand for various product volumes successfully generate a range of high-quality and high-speed products to achieve agility in the supply chain (Rahimi, Raad, Alem Tabriz, \& Motameni, 2019). Finally, the last hypothesis of this study notices that the agile methods are designed to mitigate the risk of disruption and could increase the efficiency of the supply chain (Wu \& Barnes, 2018). In summary, the findings of this research are supported by the empirical result, which shows a favourable influence of lean and agile approaches on supply chain operational efficiency in the Malaysian manufacturing industry.

\section{CONCLUSION AND IMPLICATIONS}

In conclusion, this study leads to an understanding of the effects of lean practices and agile practices on the operational performance of the supply chain in the Malaysian manufacturing industry. To achieve the operational performance of the Supply Chain, the company must concentrate on lean practices consisting of a supplier relationship, Just In Time, total quality management, pull flow and customer relationship, and agile practices consist of information technology, Just In Time, flexibility and responsiveness. Quantitative results of the research findings provide significant empirical evidence 
for the model in this report. In this analysis, the total number of hypotheses is eight, and all of them have been endorsed. In addition, the empirical results of this study identified lean and agile practices on supply chain operational performance. They have a positive relationship between them. However, this research added to the literature on Supply Chain Operational Efficiency supported by the Resource-Based View Theory.

The implications of this study were divided into two main implications, theoretical implications and practical implications. The theoretical consequences are recent additions to existing theories or tools for new theories. The effect or outcome that happens as real events occur is known as the functional implications. This study offers an empirical overview of lean practices and agile practices in the supply chain operation in the Malaysian manufacturing industry. This study derives from previous empirical studies to establish a conceptual framework for supply chain operational performance. This study indicates that researchers should use lean and agile methods to perform the operational efficiency of the supply chain in the Malaysian manufacturing industry. Based on the findings of this report, the firm will concentrate more on the supplier relationship, Just In Time, total quality management, pull flow, and customer relationship in lean practices and information technology, just in terms of time, flexibility, and responsiveness in agile supply chain operating efficiency practices. Importantly, the findings provide a context for companies to consider the criticality of aligning their resources or procedures to achieve improved supply chain operational performance.

\section{LIMITATION AND RECOMMENDATION}

The limitation of this study is that some of the respondents did not respond to the survey questionnaire, so there is a low response rate in this study. Most transport connections and distribution mechanisms between manufacturers, manufacturing facilities, and consumers have been disrupted due to the COVID-19 pandemic. Most respondents, such as industrial managers, are busy looking for effective strategies and policies to revamp manufacturing patterns and satisfy customer demand. Besides, some major industrial companies have closed their facilities or faced bankruptcy during the COVID-19 pandemic. However, this will cause many emails to not be delivered or replied to and cause the period of data collection to be extended. Lastly, the research would recommend FMM collect the latest information or remind the company to update the contact details to ease the public.

As a recommendation for future research, researchers can explore the potential benefit of lean and agile practices in the service industry to improve customer satisfaction as the service industry is getting critical, especially in the pandemic period. Besides, in the operational aspect, the researchers suggest that future researchers ensure frequent follow-up to increase the response rate. Researchers might then add a few days to the waiting period for each subsequent email as the researcher is out of control of the willingness of the targeted respondent to participate in the survey. Besides, before sending the email to the company, it is suggested to filter and screen checks against the list of companies to avoid sending the questionnaire to companies that are not operating anymore. Therefore, the period of data collection can be completed on time. Lastly, suggestions to the FMM to collect the latest contact information from each company in Malaysia, encourage the company to update the contact details once a year to increase the accuracy and reliability of the directory.

\section{ACKNOWLEDGEMENT}

The authors want to send gratitude to the Faculty of Industrial Management (FIM), the respondents, and the academic staff in FIM. Without their support, the study would not have been completed.

\section{REFERENCES}

Al-Doori, J., Alhorani, A., Social, A. A.-T. J. of, \& 2019, U. (2019). The role of Just in Time, total quality management, and supply chain management toward better operational performance. The Journal of Social Sciences Research, 5(4), 949-956. doi:10.32861/jssr.54.1295.1302

Alcaraz, J. L. G., Macías, A. A. M., Luevano, D. J. P., Fernández, J. B., López, A. de J. G., \& Macías, E. J. (2016). Main benefits obtained from a successful JIT implementation. International Journal of Advanced Manufacturing Technology, 86(9-12), 2711-2722. doi:10.1007/S00170-016-8399-5

Alzoubia, H. M., \& Yanamandra, R. (2020). Investigating the mediating role of information sharing strategy on agile supply chain. growingscience.com, 8, 273-284. doi:10.5267/j.uscm.2019.12.004

Amoako-Gyampah, K., Boakye, K. G., Adaku, E., \& Famiyeh, S. (2019). Supplier relationship management and firm performance in developing economies: A moderated mediation analysis of flexibility capability and ownership. International Journal of Production Economics, 208, 160-170. doi:10.1016/j.ijpe.2018.11.021

Ansah, R. H., \& Sorooshian, S. (2017). Effect of lean tools to control external environment risks of construction projects. Sustainable Cities and Society, 32, 348-356. doi:10.1016/j.scs.2017.03.027

Arifin, A. Z., Yanuar, \& Nuryasman, M. N. (2018). Exploring the link between supply chain agility, supply chain cost, supply chain responsiveness, global supply chain risk management, and contribution in global manufacturing: An Indonesian perspective. repository.untar.ac.id, 7(5), 353-366. Retrieved from http://repository.untar.ac.id/12419/1/B.3 ARTIKELSUPPLYCHAIN.pdf

Babalola, O., Ibem, E. O., \& Ezema, I. C. (2019). Implementation of lean practices in the construction industry: A systematic review. Building and Environment, 148, 34-43. doi:10.1016/j.buildenv.2018.10.051

Barto, J., Levit, A., \& Hana, J. (2017). Use of IT when managing a company. In Information Technology for Practice 
(pp. 1-325). Retrieved from http://www.cssi-morava.cz/new/doc/IT2017/sbornik.pdf\#page=29

Basu, G., Jeyasingam, J., Habib, M., Letchmana, U., \& Ravindran, R. (2017). The impact of supply chain management practices on the performance of private universities in Malaysia. International Journal of Supply Chain Management, 6(3), 22-35. Retrieved from https://www.researchgate.net/profile/Dr-Md-Mamun-Habib2/publication/320417579_The_impact_of_supply_chain_management_practices_on_the_performance_of_private _universities_in_Malaysia/links/5bb7c3754585159e8d8711f3/The-impact-of-supply-chain-management-prac

Beah, Z. Y. (2015). Impact of JIT practices and lean practices on operational performance in Malaysia packaging industry: Internal integration as a mediator. Universiti Sains Malaysia. Retrieved from https://core.ac.uk/download/pdf/78388976.pdf

Buergin, J., Belkadi, F., Hupays, C., Gupta, R. K., Bitte, F., Lanza, G., \& Bernard, A. (2018). A modular-based approach for Just-In-Time Specification of customer orders in the aircraft manufacturing industry. CIRP Journal of Manufacturing Science and Technology, 21, 61-74. doi:10.1016/j.cirpj.2018.01.003

Chan, A. T., Ngai, E. W., \& Moon, K. K. (2017). The effects of strategic and manufacturing flexibilities and supply chain agility on firm performance in the fashion industry. European Journal of Operational Research, 259(2), 486-499. doi:10.1016/j.ejor.2016.11.006

Chen, X., Xi, Z., \& Jing, P. (2017). A unified framework for evaluating supply chain reliability and resilience. IEEE Transactions on Reliability, 66(4), 1144-1156. doi:10.1109/TR.2017.2737822

Cheung, W., Chiang, A. H., Sambamurthy, V., \& Setia, P. (2018). Lean vs. agile supply chain: The effect of IT architectures on supply chain capabilities and performance. Pacific Asia Journal of The Association for Information Systems, 10(1), 63-88. doi:10.17705/1PAIS.10103

Chung, W., Talluri, S., \& Kovács, G. (2018). Investigating the effects of lead-time uncertainties and safety stocks on logistical performance in a border-crossing JIT supply chain. Computers \& Industrial Engineering, 118, 440-450. doi:10.1016/j.cie.2018.03.018

Conny Wang, M. W., Tan, C. L., \& Abdul Wahid, N. (2020). Supplier management practice and service quality: Critical review on mediating role of outsourcing service provider capabilities. International Journal of Industrial Management, 7(1), 9-15. doi:10.15282/ijim.7.0.2020.5750

Duarte, P., \& Amaro, S. (2018). Methods for modelling reflective-formative second order constructs in PLS: An application to online travel shopping. Journal of Hospitality and Tourism Technology, 9(3), $295-313$. doi:10.1108/JHTT-09-2017-0092/FULL/HTML

Fayezi, S., Zutshi, A., \& O’Loughlin, A. (2017). Understanding and Development of Supply Chain Agility and Flexibility: A Structured Literature Review. International Journal of Management Reviews, 19(4), 379-407. doi:10.1111/IJMR.12096

FMM Directory. (2019). Federation of Malaysia manufacturers directory. Malaysia.

Fowler, J. W., Kim, S. H., \& Shunk, D. L. (2019). Design for customer responsiveness: Decision support system for push-pull supply chains with multiple demand fulfillment points. Decision Support Systems, 123, 113071. doi:10.1016/J.DSS.2019.113071

García-Alcaraz, J. L., Realyvasquez-Vargas, A., García-Alcaraz, P., Parte, M. P. de la, Fernández, J. B., \& Macias, E. J. (2019). Effects of human factors and lean techniques on Just in Time benefits. Sustainability 2019, Vol. 11, Page 1864, 11(7), 1864. doi:10.3390/SU11071864

Gaumer, C. J., \& Shaffer, K. J. (2018). Family business succession: impact on supplier relations and customer management Article information. Human Resource Management International Digest. doi:10.1108/HRMID-052018-0104

Geyi, D. G., Yusuf, Y., Menhat, M. S., Abubakar, T., \& Ogbuke, N. J. (2020). Agile capabilities as necessary conditions for maximizing sustainable supply chain performance: An empirical investigation. International Journal of Production Economics, 222, 107501. doi:10.1016/J.IJPE.2019.09.022

Giannakis, M., Spanaki, K., \& Dubey, R. (2019). A cloud-based supply chain management system: Effects on supply chain responsiveness. Journal of Enterprise Information Management, 32(4), 585-607. doi:10.1108/JEIM-052018-0106/FULL/HTML

Gligor, D., Gligor, N., Holcomb, M., \& Bozkurt, S. (2019). Distinguishing between the concepts of supply chain agility and resilience: A multidisciplinary literature review. The International Journal of Logistics Management, 30(2), 467-487. doi:10.1108/IJLM-10-2017-0259

Gligor, D. M., Esmark, C. L., \& Holcomb, M. C. (2015). Performance outcomes of supply chain agility: When should you be agile? Journal of Operations Management, 33-34(1), 71-82. doi:10.1016/J.JOM.2014.10.008

Green, K. W., Inman, R. A., Sower, V. E., \& Zelbst, P. J. (2018). Impact of JIT, TQM and green supply chain practices on environmental sustainability. Journal of Manufacturing Technology Management, 30(1), 26-47. doi:10.1108/JMTM-01-2018-0015

Gunasekaran, A., Yusuf, Y. Y., Adeleye, E. O., Papadopoulos, T., Kovvuri, D., \& Geyi, D. G. (2018). Agile manufacturing: An evolutionary review of practices. International Journal of Production Research, 57(15-16), 5154-5174. doi:10.1080/00207543.2018.1530478

Hadrawi, H. K. (2019). The impact of firm supply performance and lean processes on the relationship between supply chain management practices and competitive performance. Uncertain Supply Chain Management, 7, 341-350. doi:10.5267/j.uscm.2018.7.003

Hair, J. F., Black, W. C., Babib, B. J., \& Anderso, R. (2010). Multivariate Data Analysis (7th ed.). New York, NY: 
Pearson Prentice Hall. doi:10.1080/15228916.2017.1374816

Hänninen, N., \& Karjaluoto, H. (2017). The effect of marketing communication on business relationship loyalty. Marketing Intelligence \& Planning, 35(4), 458-472. doi:10.1108/MIP-01-2016-0006

Haq, M. A., Hameed, I., \& Raheem, A. (2020). An empirical analysis of behavioral flexibility, relationship integration and strategic flexibility in supply chain agility: Insights from SMEs sector of Pakistan. South Asian Journal of Management Sciences, 14(1), 104-121. doi:10.21621/sajms.2020141.06

Hernandez-Matias, J. C., Ocampo, J. R., Hidalgo, A., \& Vizan, A. (2019). Lean manufacturing and operational performance: Interrelationships between human-related lean practices. Journal of Manufacturing Technology Management, 31(2), 217-235. doi:10.1108/JMTM-04-2019-0140

Hult, G. T. M., Hair Jr, J. F., Proksch, D., Sarstedt, M., Pinkwart, A., \& Ringle, C. M. (2018). Addressing endogeneity in international marketing applications of partial least squares structural equation modeling. Journal of International Marketing, 26(3), 1-21. doi:10.1509/jim.17.0151

Inman, R. A., \& Green, K. W. (2018). Lean and green combine to impact environmental and operational performance. https://doi.org/10.1080/00207543.2018.1447705, 56(14), 4802-4818. doi:10.1080/00207543.2018.1447705

Iqbal, T., Huq, F., \& Bhutta, M. K. S. (2018). Agile manufacturing relationship building with TQM, JIT, and firm performance: An exploratory study in apparel export industry of Pakistan. International Journal of Production Economics, 203, 24-37. doi:10.1016/J.IJPE.2018.05.033

Iyer, K. N. S., Srivastava, P., \& Srinivasan, M. (2019). Performance implications of lean in supply chains: Exploring the role of learning orientation and relational resources. International Journal of Production Economics, 216, 94-104. doi:10.1016/J.IJPE.2019.04.012

Jermsittiparsert, K., Sutduean, J., Sriyakul, T., \& Khumboon, R. (2019). The role of customer responsiveness in improving the external performance of an agile supply chain. Polish Journal of Management Studies, 19(2), $206-217$. doi:10.17512/PJMS.2019.19.2.17

Joshi, S., Kharat, M., Raut, R., Kamble, S., \& Kamble, S. (2017). To examine the relationships between supplier development practices and supplier-buyer relationship practices from the supplier's perspective. Benchmarking: An International Journal, 24(5), 1309-1336. doi:10.1108/BIJ-01-2016-0006

Kahle, L. R., Gurel-Atay, E., Yu, J. G., \& Ring, K. (2017). Aviary segmentation: Theory and method. In The Customer is NOT Always Right? Marketing Orientationsin a Dynamic Business World (pp. 657-657). doi:10.1007/978-3319-50008-9_179

Kaur, M., Singh, K., \& Singh, D. (2019). Synergetic success factors of total quality management (TQM) and supply chain management (SCM): A literature review. International Journal of Quality \& Reliability Management, 36(6), 842863. doi:10.1108/IJQRM-11-2017-0228

Kesen, S. E., \& Sert, M. (2019). A simulation analysis of a serial line pull system producing orders with various part types and volumes. International Journal of Modelling and Simulation, 40(3), $184-200$. doi:10.1080/02286203.2019.1588007

Khojasteh, Y. (2018). Supply chain risk management: Advanced tools, models, and developments. Supply Chain Risk Management: Advanced Tools, Models, and Developments, 1-334. doi:10.1007/978-981-10-4106-8

Lagat, C., \& Uyoga, D. (2019). Relationship between customer responsiveness, service performance and satisfaction among airline passengers in Kenya. Journal of Emerging Trends in Economics and Management Sciences, 10(2), 61-69. Retrieved from https://journals.co.za/doi/pdf/10.10520/EJC-1cf9467c15

Lee, K. L., Udin, Z. M., Hassan, M. G., Bakar, Z. A., \& Hanaysha, J. R. (2017). The power of organizational innovativeness in shaping supply chain operational performance. Advanced Science Letters, 23(9), 8579-8585. doi:10.1166/asl.2017.9933

Leite, M., \& Braz, V. (2016). Agile manufacturing practices for new product development: Industrial case studies. Journal of Manufacturing Technology Management, 27(4), 560-576. doi:10.1108/JMTM-09-2015-0073

Liu, C., Niu, Z., \& Li, Q. (2018). The impact of lean practices on performance: Based on meta-analysis and Bayesian network. Total Quality Management \& Business Excellence, 31(11-12), $1225-1242$. doi:10.1080/14783363.2018.1471352

Loon, L. K., Udin, Z. M., Hassan, M. G., Bakar, Z. A., \& Hanaysha, J. R. (2017). The power of organizational innovativeness in shaping supply chain operational performance. Advanced Science Letters, 23(9), 8579-8585. doi:10.1166/ASL.2017.9933

Lukinskiy, V., Lukinskiy, V., \& Merkuryev, Y. (2018). Modelling of transport operations in supply chains in obedience to "just-in-time" conception. Transport, 33(5), 1162-1172. doi:10.3846/transport.2018.7112

Marodin, G. A., Frank, A. G., Tortorella, G. L., \& Fetterman, D. C. (2017). Lean production and operational performance in the Brazilian automotive supply chain. Total Quality Management \& Business Excellence, 30(3-4), 370-385. doi:10.1080/14783363.2017.1308221

Meena, P. L., \& Sarmah, S. P. (2015). Supplier selection and demand allocation under supply disruption risks. The International Journal of Advanced Manufacturing Technology, 83(1), 265-274. doi:10.1007/S00170-015-7520-5

Melián-Alzola, L., Fernández-Monroy, M., \& Hidalgo-Peñate, M. (2020). Information technology capability and organizational agility: A study in the Canary Islands hotel industry. Tourism Management Perspectives, 33, 100606. doi:10.1016/J.TMP.2019.100606

Möldner, A. K., Garza-Reyes, J. A., \& Kumar, V. (2020). Exploring lean manufacturing practices' influence on process innovation performance. Journal of Business Research, 106, 233-249. doi:10.1016/J.JBUSRES.2018.09.002 
Mouaky, M., Berrado, A., \& Benabbou, L. (2019). Using a kanban system for multi-echelon inventory management: The case of pharmaceutical supply chains. International Journal of Logistics Systems and Management, 32(3-4), 496519. doi:10.1504/IJLSM.2019.098333

Mungra, Y., \& Yadav, P. K. (2019). The mediating effect of satisfaction on trust-commitment and relational outcomes in manufacturer-supplier relationship. Journal of Business \&amp; Industrial Marketing, 35(2), 219-230. doi:10.1108/JBIM-09-2018-0268

Naway, F. A., \& Rahmat, A. (2019). The mediating role of technology and logistic integration in the relationship between supply chain capability and supply chain operational performance. Uncertain Supply Chain Management, 7, 553566. doi:10.5267/j.uscm.2018.11.001

Omwoyo, J., Wanyoike, D., \& Mbeche, W. (2019). Influence of lean procurement initiatives on supply chain agility in manufacturing firms in Nakuru county, Kenya. The International Journal of Business Management and Technology, 3(4), 150-157. Retrieved from http://www.theijbmt.com/archive/0929/326823207.pdf

Onofrei, G., Prester, J., Fynes, B., Humphreys, P., \& Wiengarten, F. (2019). The relationship between investments in lean practices and operational performance: Exploring the moderating effects of operational intellectual capital. International Journal of Operations \& Production Management, 39(3), 406-428. doi:10.1108/IJOPM-04-20180201

Paul, R., Chandra, R. P. J. B., Chalup, S. K., \& Raravi, G. (2017). Improving operational performance in service delivery organizations by using a metaheuristic task allocation algorithm. In BPM (Industry Track) (pp. 25-37). Retrieved from http://ceur-ws.org/Vol-1985/BPM17industry03.pdf

Phan, A., Nguyen, H., Nguyen, H., Sustainability, Y. M.-, \& 2019, U. (2019). Effect of total quality management practices and JIT production practices on flexibility performance: Empirical evidence from international manufacturing plants. mdpi.com, 11(11), 3093. doi:10.3390/su11113093

Pinto, J. L. Q., Matias, J. C. O., Pimentel, C., Azevedo, S. G., \& Govindan, K. (2018). Just in Time Factory: Implementation Through Lean Manufacturing Tools. Cham: Springer International Publishing. doi:10.1007/978-3319-77016-1

Prajogo, D., Toy, J., Bhattacharya, A., Oke, A., \& Cheng, T. C. E. (2018). The relationships between information management, process management and operational performance: Internal and external contexts. International Journal of Production Economics, 199, 95-103. doi:10.1016/J.IJPE.2018.02.019

Rahimi, A., Raad, A., Alem Tabriz, A., \& Motameni, A. (2019). Providing an interpretive structural model of agile supply chain practices. Journal of Modelling in Management, 15(2), 661-684. doi:10.1108/JM2-09-2018-0142

Rahman, I. A., Al-Emad, N., \& Nagapan, S. (2016). Projects delay factors of Saudi Arabia construction industry using PLS-SEM path modelling approach. In In MATEC Web of Conferences (Vol. 81). doi:10.1051/matecconf/20168107001

Rajagopal, P., Azar, N. A. Z., Bahrin, A. S., \& Appasamy, G. (2016). Determinants of supply chain responsiveness among firms in the manufacturing industry in Malaysia. International Journal of Supply Chain Management, 5(3). Retrieved from http://ijis-scm.bsne.ch/ojs.excelingtech.co.uk/index.php/IJSCM/article/download/1280/12804662-1-PB.pdf

Recker, J., Holten, R., Hummel, M., \& Rosenkranz, C. (2017). How agile practices impact customer responsiveness and development success: A field study. https://doi.org/10.1177/875697281704800208, 48(2), 99-121. doi: $10.1177 / 875697281704800208$

Ritter, T., \& Walter, A. (2008). Functions, trust, and value in business relationships. Advances in Business Marketing and Purchasing, 14, 129-146. doi:10.1016/S1069-0964(08)14004-2

Romero, D., Gaiardelli, P., Powell, D., Wuest, T., \& Thürer, M. (2019). Total quality management and quality circles in the digital lean manufacturing world. IFIP Advances in Information and Communication Technology, 566, 3-11. doi:10.1007/978-3-030-30000-5_1

Santouridis, I., \& Veraki, A. (2017). Customer relationship management and customer satisfaction: The mediating role of relationship quality. Total Quality Management \& Business Excellence, 28(9-10), 1122-1133. doi:10.1080/14783363.2017.1303889

Schneider, T., \& Wheeler-Kingshott, C. A. M. (2014). Q-Space imaging: A model-free approach. In Quantitative MRI of the Spinal Cord (pp. 146-155). Academic Press. doi:10.1016/B978-0-12-396973-6.00010-1

Schonberger, R. J., \& Brown, K. A. (2017). Missing link in competitive manufacturing research and practice: Customerresponsive concurrent production. Journal of Operations Management, 49-51(1), 83-87. doi:10.1016/J.JOM.2016.12.006

Schuberth, F., Rademaker, M. E., \& Henseler, J. (2020). Estimating and assessing second-order constructs using PLSPM: The case of composites of composites. Industrial Management \&amp; Data Systems, 120(12), $2211-2241$. doi:10.1108/IMDS-12-2019-0642

Shahbaz, M. S., Rasi, R. Z. R., Ahmad, M. F. Bin, \& Sohu, S. (2018). The impact of supply chain collaboration on operational performance: Empirical evidence from manufacturing of Malaysia. International Journal of Advanced and Applied Sciences, 5(8), 64-71. doi:10.21833/IJAAS.2018.08.009

Shang, D., \& Ren, J. (2017). Analyses on the influencing factors of JIT models on auto parts performance. In 4th International Conference on Management Science, Innovation, and Technology 2017 (pp. 156-165). Retrieved from http://icmsit.ssru.ac.th/icmsit/fmsicmsit/images/Analyses-on-the-Influencing-Factors-of-JIT-Models-onAuto-Parts-Performance.pdf 
Sharma, S., \& Modgil, S. (2019). TQM, SCM and operational performance: an empirical study of Indian pharmaceutical industry. Business Process Management Journal, 26(1), 331-370. doi:10.1108/BPMJ-01-2018-0005

Soltan, H., \& Mostafa, S. (2015). Lean and agile performance framework for manufacturing enterprises. Procedia Manufacturing, 2, 476-484. doi:10.1016/J.PROMFG.2015.07.082

Tarafdar, M., \& Qrunfleh, S. (2016). Agile supply chain strategy and supply chain performance: Complementary roles of supply chain practices and information systems capability for agility. International Journal of Production Research, 55(4), 925-938. doi:10.1080/00207543.2016.1203079

Tseng, S.-H., Wee, H.-M., Reong, S., \& Wu, C.-I. (2019). Considering JIT in Assigning Task for Return Vehicle in Green Supply Chain. Sustainability, 11(22), 6464. doi:10.3390/SU11226464

Visser, L., Hoefnagels, R., \& Junginger, M. (2020). Wood pellet supply chain costs: A review and cost optimization analysis. Renewable and Sustainable Energy Reviews, 118, 109506. doi:10.1016/J.RSER.2019.109506

Wagner, S. M., Grosse-Ruyken, P. T., \& Erhun, F. (2018). Determinants of sourcing flexibility and its impact on performance. International Journal of Production Economics, 205, 329-341. doi:10.1016/J.IJPE.2018.08.006

Wu, C., \& Barnes, D. (2018). Design of agile supply chains including the trade-off between number of partners and reliability. The International Journal of Advanced Manufacturing Technology, 97(9-12), 3683-3700. doi:10.1007/s00170-018-2205-5

Wu, K. (2019). Proactive Pull Systems with Applications. SSRN Electronic Journal. doi:10.2139/SSRN.3387962

Zhang, J., Li, H., Golizadeh, H., Zhao, C., Lyu, S., \& Jin, R. (2020). Reliability evaluation index for the integrated supply chain utilizing BIM and lean approaches. Engineering, Construction and Architectural Management, 27(5), 9971038. doi:10.1108/ECAM-12-2018-0542

Zhou, B. (2012). Lean principles, practices, and impacts: A study on small and medium-sized enterprises (SMEs). Annals of Operations Research 2012 241:1, 241(1), 457-474. doi:10.1007/S10479-012-1177-3

\section{CONFLICT OF INTEREST}

The author(s), as noted, certify that they have NO affiliations with or involvement in any organization or agency with any financial interest (such as honoraria; educational grants; participation in speakers' bureaus; membership, jobs, consultancies, stock ownership, or other equity interest; and expert testimony or patent-licensing arrangements), or nonfinancial interest (such as personal or professional relationships, affiliations, expertise or beliefs) in the subject matter or materials addressed in this manuscript. 


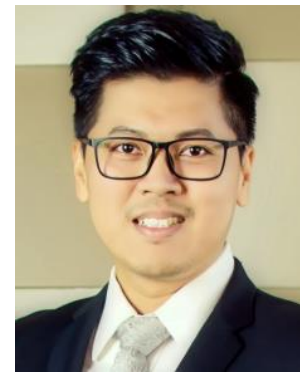

Author's Full Name: Khai Loon, Lee

Author's email: leekhailoon@ump.edu.my

Author Professional Bio (not more than 50 words): Ts. Dr. Lee Khai Loon is a Senior Lecturer in Faculty of Industrial Management (FIM), Universiti Malaysia Pahang (UMP). He specialized in supply chain management, technology management, operation management, industrial engineering, and business management. He holds a Doctor of Philosophy $(\mathrm{PhD})$ in Supply Chain Management and Bachelor Degree in Technology Management from School of Technology Management and Logistics, Universiti Utara Malaysia (UUM). He has a long industrial experience and teaching undergraduate and postgraduate students in the university. He is a chartered member of The Chartered Institute of Logistics and Transport (CMILT) Malaysia and UK, the Professional Technologist in Malaysia Board of Technologists (MBOT), the Certified Trainer (TTT) by HRDF, the Certified Trainer for MonsoonSIM, and Mendeley Advisor.

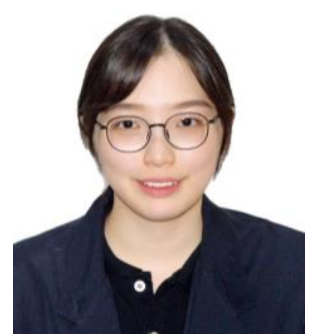

Author's Full Name: Teh Xing Qi

Author's Email: qiqiteh88@gmail.com

Author Professional Bio (not more than 150 words): Teh Xing Qi is a final year student from Universiti Malaysia Pahang. In Universiti Malaysia Pahang, she obtained a bachelor's degree in Industrial Technology Management with Honors. 